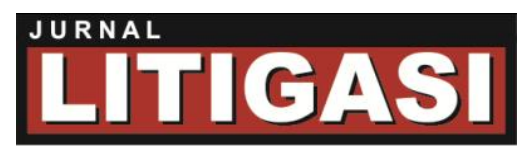

Available online at: http://ejournal.unpas.ac.id/index.php/litigasi

Litigasi, Vol. 16(1), 2015, 2582-2609

DOI: http://dx.doi.org/10.23969/litigasi.v16i1.93

\title{
LANGKAH-LANGKAH PENYUSUNAN BUKU PERSYARATAN SEBAGAI PRASYARAT PENDAFTARAN PRODUK INDIKASI GEOGRAFIS
}

\author{
Tatty A. Ramli
}

Dosen Fakultas Hukum Universitas Islam Bandung, Jl. Ranggagading No. 8, Telp: 022-4203368 Psw. 403, Hp: 08122308716 ,E-mail: tattyramli@gmail.com

Yeti Sumiyati

Dosen Fakultas Hukum Universitas Islam Bandung, Jl. Ranggagading No. 8, Telp: 022-4203368 Psw. 403, Hp: 081320913073 , E-mail: yeti_sumiyati74@yahoo.com

\section{Arif Firmansyah}

Dosen Fakultas Hukum Universitas Islam Bandung, Jl. Ranggagading No. 8, Telp: 022-4203368 Psw. 403, Hp: 0812129111244, E-mail: arifunisba05@gmail.com

\section{Frency Siska}

Dosen Fakultas Hukum Universitas Islam Bandung, Jl. Ranggagading No. 8, Telp: 022-4203368 Psw. 403, Hp: 081802202338 , E-mail: frency_siska@yahoo.com

\begin{abstract}
ABSTRAK
Belum terdaftarnya Beras Pandanwangi Cianjur di Dirjen HKI sebagai produk yang berkarakteristik Indikasi Geografis, mengakibatkan penegakkan hukum terhadap praktik-praktik pemalsuan produk tersebut sulit dilakukan. Kendala teknis dan kurangnya budaya pendokumentasian menyebabkan terhambatnya penyusunan Buku Persyaratan yang merupakan prasyarat Pendaftaran Hak Indikasi Geografis. Untuk itu, perlu ditemukan langkah-langkah penyusunan Buku Persyaratan melalui permasalahan apakah terdapat standarisasi dalam penyusunan Buku Persyaratan dan bagaimana langkah penyusunan Buku Persyaratan Beras Pandanwangi Cianjur. Penelitian ini menggunakan metode yuridis normatif dengan spesifikasi deskriptif analitis. Hasil penelitian mengungkapkan bahwa Peraturan Pemerintah Nomor 51 Tahun 2007 Tentang Indikasi Geografis baru mengatur standarisasi uraian yang harus dimuat dalam Buku Persyaratan sementara standarisasi teknisnya belum diatur. Langkah penyusunan Buku Persyaratan Indikasi Geografis diawali dengan penyusunan renstra oleh Pemerintah Kabupaten Cianjur dan dinas terkait untuk membentuk lembaga Masyarakat Perwakilan Indikasi Geografis (MPIG) dan distribusi tugas untuk mengisi uraian Buku Persyaratan sesuai kompetensinya.
\end{abstract}

Kata Kunci: Buku, Persyaratan, Indikasi Geografis, Pandanwangi.

Copyright @ 2015 , LITIGASI, p-ISSN: 0853-7100; e-ISSN: 2442-2274 
Available online at: http://ejournal.unpas.ac.id/index.php/litigasi

Litigasi, Vol. 16(1), 2015, 2582-2609

DOI: http://dx.doi.org/10.23969/litigasi.v16i1.93

\begin{abstract}
Registering and protecting Beras Pandanwangi CIANJUR aims to avoid counterfeit product. Protected Geographical Indications are a relevant and effective tool to showcase the quality of the products, protect their names and reputations, and develop profitable market. A Book of Specification of Geographical Indications as the main requirement of registration decribes the good and the production methods. the registration system is first to file. Inter professional organization of Beras Pandanwangi CIANJUR which bring together all kind of operators such farmers, processors and traders contribute all the information into the book, submit and manage the registration. The result revealed that the Geographical Existing rules (Peraturan Pemerintah Nomor 51 Tahun 2007 Tentang Indikasi Geografis) only determine standards of information. Due to technical constrains and lack of cultural documentation, it is need to set up a technical standardization how to fiil in the information. The effort shall begin with strategic planning by local government by forming the Inter Professional organization (MPIG) of Beras Pandanwangi Cianjur and distributing task according to their competencies.
\end{abstract}

Keyword: Book, Specification, Geographical Indications, Pandanwangi.

Copyright (C) 2015, LITIGASI, p-ISSN: 0853-7100; e-ISSN: 2442-2274 
Available online at: http://ejournal.unpas.ac.id/index.php/litigasi

Litigasi, Vol. 16(1), 2015, 2582-2609

DOI: http://dx.doi.org/10.23969/litigasi.v16i1.93

\section{PENDAHULUAN}

Pasca diundangkannya Peraturan Pemerintah Nomor 51 Tahun

2007 Tentang Indikasi Geografis, produk hasil alam dan kerajinan yang sudah terdaftar di Dirjen HKI berjumlah 20 produk. Produk IG yang telah terdaftar tersebut adalah Kopi Arabika Kintamani Bali, Ukir Jepara, lada Putih Muntok, Kopi Arabika Gayo, Tembakau Hitam Sumedang, Tembakau Mole Sumedang, Susu Kuda Sumbawa, Kangkung Lombok, Madu Sumbawa, Beras Adan Krayan, Kopi Arabika Banjawa Flores, Purwaceng Dieng, Carica Dieng, Vanilla Kepulauan Alor, Kopi Arabika Kalosi Enrekang, Ubi Cilembu Sumedang, Salak Pondoh Sleman, Nilam Aceh, Kopi Arabika java Preanger, dan Kopi Arabika Ijen raung (http://www.dgip.go.id, 2013).

Pendaftaran berimplikasi terhadap efektifnya perlindungan hukum terhadap produk-produk Indikasi Geografis. Indikasi Geografis melindungi tanda yang mengindikasikan nama wilayah yang menghasilkan suatu produk hasil alam atau kerajinan yang mempunyai karakter dan kualitas tertentu karena dipengaruhi oleh faktor alam/geografis atau faktor manusia atau keduanya.

Beras Pandanwangi Cianjur sebetulnya menjadi target Dirjen Hak Kekayaan Intelektual Ahmad M. Ramli untuk diproses perlindungan hukumnya melalui pendaftaran, setelah beras Adan Krayaan diajukan pendaftarannya oleh Asosiasi Masyarakat Adat Perlindungan Beras Adan Krayan Kalimantan Timur. (Anonim, "Bertambah, Produk Indikasi Geografis yang Dilindungi: Ketimbang 
ribut dengan negara tetangga, lebih baik ajukan permohonan resmi demi perlindungan hukum", (http://www.hukumonline, 2013). Namun, sampai saat ini jangankan pendaftaran, Masyarakat Perlindungan Indikasi Geografis (MPIG) sebagai lembaga pemohon dan Buku Persyaratan pun belum terbentuk. Padahal, masyarakat petani ingin segera Beras Pandanwangi didaftarkan karena banyaknya pemalsuan terhadap Beras pandanwangi Cianjur.

H. Pepen Jaenudin, dari Asosiasi petani Kec. Warungkondang Kab. Cianjur menjelaskan bahwa sampai saat ini para pelaku pemalsuan beras Pandanwangi dapat dengan bebas menjalankan aksinya di pasar tanpa hukuman atau sanksi. Praktik penggunaan essence oleh produsen tidak bertanggung jawab terhadap beras varietas lain agar seolah-olah beras tersebut adalah beras Pandanwangi Cianjur menambah luasnya praktek penjualan beras Pandanwangi palsu. Lemahnya pengawasan dan ketiadaan sanksi atas tindakan tersebut membuat konsumen kesulitan membedakan keaslian beras Pandanwangi Cianjur (Handri Handrian, “Elegi Pandan Wangi", Pikiran Rakyat, Rabu, 10 Juni 2009).

Beberapa tahun terakhir, beberapa pihak seperti tim peneliti IPB, asosiasi pedagang beras pandanwangi, asosiasi petani beras pandanwangi, dinas pertanian dan pemerintah Cianjur juga dari beberapa keluhan konsumen, ditenggarai telah terjadi pemalsuan terhadap beras Pandanwangi Cianjur (http://www.indosiar.com, 2007). Pemalsuan tersebut melalui beberapa modus, beras yang bukan berasal dari benih pandanwangi asli dioplos beras pandanwangi asli, beras bukan 
Available online at: http://ejournal.unpas.ac.id/index.php/litigasi

Litigasi, Vol. 16(1), 2015, 2582-2609

DOI: http://dx.doi.org/10.23969/litigasi.v16i1.93

pandanwangi diberi essence pewangi serupa pandanwangi dengan bahan kimia, atau dengan menjual beras pandanwangi dalam kemasan yang labelnya mencantumkan kata "Cianjur".

Praktik pemalsuan tersebut semata-mata terjadi karena Beras Pandanwangi Cianjur belum didaftarkan. Untuk syarat pendaftaran, maka terbentuknya lembaga yang menjadi pemohon yaitu MPIG Beras Pandanwangi Cianjur dan Buku Persyaratan menjadi suatu hal yang mutlak dilakukan.

Faktanya, sampai saat ini kedua syarat tersebut belum terbentuk. Padahal, tim peneliti telah melakukan edukasi kepada masyarakat petani dan pemerintah daerah sejak Tahun 2009 melalui kegiatan Pengabdian Kepada Masyarakat (PKM). Berdasarkan data yang diperoleh juga tersimpul bahwa komitmen dari masyarakat petani, pedagang dan pemerintah daerah tidak diragukan lagi untuk segera melindungi Beras Pandanwangi Cianjur dari aspek hukum.

Masalahnya adalah koordinasi dalam hal pendokumentasian data secara teratur dan lengkap yang dapat dijadikan bukti untuk menghindari penggunaan Indikasi Geografis dari perbuatan curang, belum optimal dilakukan (Yeti Sumiyati, 2010). Diperlukan langkah-langkah dalam melindungi Beras Pandanwangi Cianjur.

Berdasarkan uraian tersebut, maka dalam artikel hasil penelitian ini akan dibatasi masalah-masalah sebagai berikut: 1) Apakah terdapat standarisasi dalam penyusunan Buku Persyaratan sebagai prasarat perlindungan hukum Indikasi 
Available online at: http://ejournal.unpas.ac.id/index.php/litigasi

Litigasi, Vol. 16(1), 2015, 2582-2609

DOI: http://dx.doi.org/10.23969/litigasi.v16i1.93

Geografis Beras Pandanwangi Cianjur berdasarkan Peraturan Pemerintah Nomor 51 Tahun 2007 Tentang Indikasi Geografis? dan 2) Bagaimana langkah penyusunan Buku Persyaratan Beras Pandanwangi Cianjur sebagai salah satu prasyarat pendaftaran Indikasi Geografis?

\section{METODE PENELITIAN}

Metode digunakan untuk mencapai tujuan tersusunnya langkah-langkah penyusunan Buku Persyaratan sebagai prasyarat perlindungan hukum Indikasi Geografis Beras Pandanwangi Cianjur adalah yuridis normatif yang mengkaji data kepustakaan yang merupakan data sekunder.

Spesifikasi penelitian menggunakan deskriptif analitis. Dalam penelitian dengan spesifikasi deskriptif analitis, peneliti akan mengungkapkan dan menganalisis gejala-gejala hukum yang ada pada saat ini (Soerjono Soekanto, 1986).

Materi penelitian ini adalah tentang perlindungan Indikasi geografis sebagai bagian dari perlindungan HKI dan langkah-langkah penyusunan Buku Persyaratan sebagai prasyarat pendaftaran untuk mendapatkan perlindungan hukum Indikasi Geografis Beras Pandanwangi Cianjur. Penelitian dilakukan di Kota Bandung, Kota Jakarta dan Kabupaten Cianjur.

Teknik pengumpulan data sekunder berupa bahan hukum primer, bahan hukum sekunder, dan bahan hukum tertier dilakukan melalui studi pustaka. 
Dengan mengadakan studi kepustakaan, akan diperoleh data awal untuk dipergunakan dalam penelitian lapangan (Ronny Hanitijo Soemitro, 1994) melalui wawancara. Oleh karena penelitian ini merupakan penelitian hukum normatif, maka analisis data dilakukan secara kualitatif.

\section{HASIL PENELITIAN DAN ANALISIS}

\section{A.Standarisasi Dalam Penyusunan Buku Persyaratan Sebagai Prasyarat} Perlindungan Hukum Indikasi Geografis Beras Pandanwangi Cianjur Berdasarkan Peraturan Pemerintah Nomor 51 Tahun 2007 Tentang Indikasi Geografis.

Perlindungan hukum Indikasi Geografis baru akan terjadi apabila telah dilakukan pendaftaran. Syarat sudah terdaftar (Registered) merupakan satusatunya alternatif untuk memperoleh perlindungan hukum Indikasi Geografis, sesuai dengan sistem pendaftaran yang dianut oleh Undang-Undang Nomor 15 Tahun 2001 Tentang Merek (UU Merek) dan Peraturan Pemerintah Nomor 51 Tahun 2007 tentang Indikasi Geografis (PP Tentang Indikasi Geografis) yaitu sistem first to file atau sistem konstitutif. Dalam sistem konstitutif, pendaftaran melahirkan hak atas merek (mutatis mutandis terhadap Indikasi Geografis) dan pihak ini secara eksklusif dapat memakai merek tersebut. Artinya, hak eksklusif atas suatu merek diberikan karena adanya pendaftaran / required by registration (Muhamad Jumhana, 2006). Produk 
Available online at: http://ejournal.unpas.ac.id/index.php/litigasi

Litigasi, Vol. 16(1), 2015, 2582-2609

DOI: http://dx.doi.org/10.23969/litigasi.v16i1.93

Indikasi Geografis baru dapat terdaftar apabila syarat pendaftaran telah terpenuhi. Penyusunan Buku Persyaratan merupakan salah satu prasyarat pendaftaran selain lembaga pemohon terintegrasi yang tergabung dalam wadah MPIG.

Antara lembaga pemohon pendaftaran atau MPIG dengan Buku Persyaratan merupakan syarat yang berkelindan satu sama lain. Uraian dalam Buku Persyaratan baru dapat terisi apabila telah terbentuk lembaga pemohon pendaftaran yang terintegrasi antara aparat Desa, aparat Pemerintah Kabupaten, kelompok tani, produsen/ bandar, dan kelompok konsumen.

Pengintegrasian lembaga pemohon pendaftaran yang berkompetensi mengisi Buku Persyaratan sebagai prasyarat pendaftaran, sangat konsisten dengan perlindungan Indikasi Geografis sebagai rezim komunal dan kolektif. Artinya, sifat kepemilikannya kolektif. Hak eksklusif Indikasi Geografis dimiliki oleh masyarakat yang mendiami suatu kawasan geografis tertentu. Oleh karena itu, Indikasi Geografis merupakan perekat antara produk dengan daerah asal yang melekat di dalamnya masyarakat petani, produsen, aparat pemerintahan, dan konsumen (Miranda Risang Ayu, 2006).

Mengingat hanya Indikasi Geografis yang pertama terdaftar di Dirjen HKI yang memperoleh hak eksklusif (Muhamad Jumhana, 2006. Lihat juga M. Yahya Harahap, 1996), yaitu hak untuk memakai Indikasi Geografis, maka kedua syarat pendaftaran tersebut di atas harus segera dibentuk. Syarat

Copyright @ $\odot$ 2015, LITIGASI, p-ISSN: 0853-7100; e-ISSN: 2442-2274 
Available online at: http://ejournal.unpas.ac.id/index.php/litigasi

Litigasi, Vol. 16(1), 2015, 2582-2609

DOI: http://dx.doi.org/10.23969/litigasi.v16i1.93

pembentukan lembaga pemohon maupun Buku Persyaratan diatur dalam Peraturan Pemerintah No. 51 Tahun 2007 Tentang Indikasi Geografis.

Terkait tentang lembaga pemohon pendaftaran, Pasal 2 angka (3) Peraturan Pemerintah No. 51 Tahun 2007 Tentang Indikasi geografis telah menentukan pihak yang dapat menjadi pemohon pendaftaran. Namun, penentuan pihak yang dapat menjadi pemohon pendaftaran dalam pasal tersebut kurang berfungsi apabila dikaitkan dengan pengisian Buku Persyaratan. Sehingga dalam penelitian ini, lembaga yang mendekati tataran ideal adalah lembaga yang kami temukan dalam penelitian Hibah bersaing 2008-2009 (Tatty A, Ramli \& Yeti Sumiyati, 2009) Lembaga dimaksud adalah gabungan perwakilan atau terintegrasi dari 1) lembaga yang mewakili masyarakat di daerah yang memproduksi barang yang bersangkutan, yang terdiri atas: pihak yang mengusahakan barang yang merupakan hasil alam atau kekayaan alam; produsen barang hasil pertanian; pembuat barang-barang kerajinan tangan atau hasil industri; atau pedagang yang menjual barang tersebut; 2) lembaga yang diberi kewenangan untuk itu, dalam hal ini pemerintah daerah dan 3) kelompok konsumen barang yang dapat diindikasikan sebagai produk IndikasiGeografis.

Sementara itu, terkait dengan uraian yang harus diisi dalam Buku Persyaratan, Pasal 6 Ayat (3) Peraturan Pemerintah No. 51 Tahun 2007 tentang Indikasi Geografis telah menentukan batasannya. Beberapa uraian

Copyright $\odot$ 2015, LITIGASI, p-ISSN: 0853-7100; e-ISSN: 2442-2274 
Available online at: http://ejournal.unpas.ac.id/index.php/litigasi

Litigasi, Vol. 16(1), 2015, 2582-2609

DOI: http://dx.doi.org/10.23969/litigasi.v16i1.93

dalam Buku Persyaratan yang harus diisi pihak Pemohon adalah : a. nama Indikasi Geografis yang dimohonkan pendaftarannya; b. nama barang yang dilindungi oleh Indikasi Geografis; c. uraian mengenai karakteristik dan kualitas yang membedakan barang tertentu dengan barang lain yang memiliki kategori sama, dan menjelaskan tentang hubungannya dengan daerah tempat barang tersebut dihasilkan; $d$. uraian mengenai lingkungan geografis serta faktor alam dan faktor manusia yang merupakan satu kesatuan dalam memberikan pengaruh terhadap kualitas atau karakteristik dari barang yang dihasilkan; e. uraian tentang batas-batas daerah dan/atau peta wilayah yang dicakup oleh Indikasi Geografis; f. uraian mengenai sejarah dan tradisi yang berhubungan dengan pemakaian Indikasi Geografis untuk menandai barang yang dihasilkan di daerah tersebut, termasuk pengakuan dari masyarakat mengenai Indikasi Geografis tersebut; g. uraian yang menjelaskan tentang proses produksi, proses pengolahan, dan proses pembuatan yang digunakan sehingga memungkinkan setiap produsen di daerah tersebut untuk memproduksi, mengolah, atau membuat barang terkait; $h$. uraian mengenai metode yang digunakan untuk menguji kualitas barang yang dihasilkan; dan g. label yang digunakan pada barang dan memuat Indikasi Geografis.

Melihat uraian dalam Buku Persyaratan tersebut, maka: 1) hanya masyarakat petani yang memiliki kompetensi menguraikan mengenai sejarah dan tradisi yang berhubungan dengan pemakaian Indikasi-Geografis untuk 
Available online at: http://ejournal.unpas.ac.id/index.php/litigasi

Litigasi, Vol. 16(1), 2015, 2582-2609

DOI: http://dx.doi.org/10.23969/litigasi.v16i1.93

menandai barang yang dihasilkan di daerah tersebut; 2) Konsumen yang memiliki kompetensi untuk memberikan pengakuan atau testimoni mengenai keunggulan produk Indikasi-Geografis; 3) menjadi kompetensi Dinas Pertanian, untuk memberikan uraian mengenai karakteristik khas dan kualitas yang membedakan barang tertentu dengan barang lain yang memiliki kategori sama, dan menjelaskan tentang hubungannya dengan daerah tempat barang tersebut dihasilkan; uraian mengenai pengaruh lingkungan geografis dan alam serta faktor manusia terhadap kualitas atau karakteristik barang tersebut; dan uraian tentang batas-batas wilayah dan/atau peta daerah yang dilindungi oleh Indikasi-geografis; 4) Dinas Perdagangan, Dinas Koperasi dan UKM, serta Produsen atau pengusaha atau bandar mempunyai kompetensi menjelaskan tentang proses produksi, proses pengolahan, proses pembuatan yang digunakan sehingga memungkinkan setiap produsen di daerah tersebut dapat memproduksi, mengolah, atau membuat barang terkait; 5) Pemerintah daerah cq bagian Hukum Kabupaten Sumedang memiliki kompetensi dalam hal pengurusan birokrasi pemerintahan terkait dengan proses pendaftaran IndikasiGeografis ke Dirjen HKI.

Berdasarkan uraian tersebut, Peraturan Pemerintah No. 51 Tahun 2007 tentang Indikasi Geografis telah menentukan batasan yang termuat dalam Buku Persyaratan berupa uraian yang dikemukakan di atas. Namun demikian, dalam praktek masyarakat menemukan kesulitan dalam menyusun

Copyright @ C 2015, LITIGASI, p-ISSN: 0853-7100; e-ISSN: 2442-2274 
Available online at: http://ejournal.unpas.ac.id/index.php/litigasi

Litigasi, Vol. 16(1), 2015, 2582-2609

DOI: http://dx.doi.org/10.23969/litigasi.v16i1.93

Buku Persyaratan, sehingga muncul keragaman bentuk penyusunan Buku Persyaratan, baik dari segi teknis maupun substansi. Dalam Penyusunan Buku Persyaratan Indikasi Geografis belum ada standar baku tentang aturan penulisan misalnya: aturan mengenai jumlah halaman, sistematika atau teknik penulisan, serta substansi yang harus dijabarkan dari uraian-uraian yang ditentukan oleh Pasal 6 Ayat (3) Peraturan Pemerintah No. 51 Tahun 2007 Tentang Indikasi Geografis.

Berdasarkan data yang telah diolah, penyusunan Buku Persyaratan Indikasi Geografis yang merujuk pada Pasal 6 Ayat (3) Peraturan Pemerintah No. 51 Tahun 2007 tentang Indikasi Geografis dirasa belum cukup untuk dijadikan pedoman. Peraturan Pemerintah tersebut hanya menentukan uraian - uraian secara umum, tidak dijabarkan lagi lebih spesifik baik secara teknis maupun substantif, sehingga diantara Buku Persyaratan dari produk Indikasi Geografis yang sudah terdaftar di Dirjen HKI banyak ditemukan perbedaan baik secara teknis maupun secara subtantif.

Adapun Buku Persyaratan atas produk Indikasi Geografis yang telah kami peroleh adalah Persyaratan Kopi Kintamani Bali, Buku Persyaratan Indikasi Geografis Carica Dieng, Buku Persyaratan Indikasi Geografis Ubi Cilembu Sumedang, Buku Persyaraan Indikasi Geografis Kangkung Lombok, dan Buku Persyaratan Indikasi Geografis Kopi Arabica Flores Bajawa. Selain itu kami juga menganalisis Buku Persyaratan Indikasi Geografis Kopi Arabica

Copyright $\odot$ 2015, LITIGASI, p-ISSN: 0853-7100; e-ISSN: 2442-2274 
Available online at: http://ejournal.unpas.ac.id/index.php/litigasi

Litigasi, Vol. 16(1), 2015, 2582-2609

DOI: http://dx.doi.org/10.23969/litigasi.v16i1.93

Gayo, Buku Persyaratan Indikasi Geografis Susu Kuda Sumbawa, Buku Persyaratan Indikasi Geografis Lada Putih Muntok, Buku Persyaratan Indikasi Geografis Mebel Ukir Jepara, dan Buku Persyaratan Indikasi Geografis Tembakau Hitam Sumedang.

Guna memenuhi Pasal 6 Ayat (3) Peraturan Pemerintah No. 51 Tahun 2007 tentang Indikasi Geografis, maka hendaknya sistematika penyusunan setiap Buku Persyaratan minimal mencakup uraian-uraian sebagaimana yang disyaratkan. Namun di dalam praktek, umumnya sistematika penyusunan Buku Persyaratan tidak sama persis sebagaimana yang ditentukan oleh Peraturan Pemerintah tentang Indikasi Geografis, seperti perbedaan tata letak pemaparan substansi dan penggunaan judul dari uraian.

Salah satu contohnya adalah Buku Persyaratan Indikasi Geografis Ubi Cilembu, yang disusun dengan sistematika sebagai berikut : a. Nama Indikasi Geografis; b. Nama Barang; c. Karakteristik dan Kualitas Barang; d. Pengaruh Lingkungan Geografis, Alam, dan Faktor Manusia; e. Batas Geografis; f. Sejarah; g. Budidaya dan Pengolahan; h. Metode Pengawasan; i. Keterunutan; dan j. Label. Terdapat perbedaan antara sistematika atau uraian dalam Buku Persyaratan Indikasi Geografis Ubi Cilembu dengan uraian yang ditentukan dalam Peraturan Pemerintah tentang Indikasi Geografis. Dalam Buku Persyaratan Ubi Cilembu juga menerangkan uraian tentang Metode Pengawasan dan Keterunutan, sedangkan di dalam Peraturan Pemerintah

Copyright @ C 2015, LITIGASI, p-ISSN: 0853-7100; e-ISSN: 2442-2274 
Available online at: http://ejournal.unpas.ac.id/index.php/litigasi

Litigasi, Vol. 16(1), 2015, 2582-2609

DOI: http://dx.doi.org/10.23969/litigasi.v16i1.93

tentang Indikasi Geografis uraian mengenai keterunutan tidak ditentukan, sehingga sistematika di dalam Buku Persyaratan Indikasi Geografis Ubi Cilembu ada 10 (sepuluh) uraian, berbeda dengan Peraturan Pemerintah tentang Indikasi Geografis yang terdiri atas 9 (sembilan) uraian.

Di samping itu, uraian mengenai metode yang digunakan untuk menguji kualitas barang yang dihasilkan sebagaimana disyaratkan oleh Peraturan Pemerintah tentang Indikasi Geografis, tidak terdapat di dalam Buku Persyaratan Indikasi Geografis Ubi Cilembu. Kemudian, sistematika atau uraian yang digunakan dalam menyusun Buku Persyaratan Indikasi Geografis produk yang satu dengan yang lainnya juga berbeda-beda. Seperti Buku Persyaratan Indikasi Geografis Mebel Ukir Jepara, hanya mencantumkan 9 (sembilan) uraian atau sistematika, dimana uraian tentang keterunutan tidak dicantumkan. Demikian pula halnya dengan Buku Persyaratan Indikasi Geografis Tembakau Hitam Sumedang yang mencantumkan 10 (sepuluh) uraian yang juga mencantumkan uraian tentang keterunutan. Ada juga Buku Persyaratan Indikasi Geografis yang menambahkan uraian lain selain dari yang tersebut di atas yaitu seperti di dalam Buku Persyaratan Indikasi Geografis Susu Kuda Sumbawa, dimana uraiannya ditambah dengan uraian mengenai manfaat dan keunggulan susu kuda dan uraian mengenai pencatatan.

Memperhatikan kembali ketentuan mengenai Buku Persyaratan dalam Peraturan Pemerintah tentang Indikasi Geografis, Peraturan Pemerintah 
Available online at: http://ejournal.unpas.ac.id/index.php/litigasi

Litigasi, Vol. 16(1), 2015, 2582-2609

DOI: http://dx.doi.org/10.23969/litigasi.v16i1.93

tersebut tidak menentukan judul dari setiap uraian yang harus digunakan dalam penyusunan Buku Persyaratan. Akibatnya, judul-judul dari setiap uraian yang ditentukan Peraturan Pemerintah tentang Indikasi Geografis tersebut yang digunakan dalam menyusun Buku Persyaratan Indikasi Geografis produk yang satu dengan Buku Persyaratan Indikasi Geografis produk yang lainnya berbedabeda.

Secara substantif diantara Buku Persyaratan sebagaimana tersebut di atas, uraian-uraian yang ditentukan oleh Pasal 6 ayat (3) Peraturan Pemerintah No. 51 Tahun 2007 tentang Indikasi Geografis lebih lengkap dijabarkan atau dipaparkan oleh Buku Persyaratan Indikasi Geografis Carica Dieng, meskipun terdapat beberapa penjabaran yang diletakkan tidak pada tempatnya. Penjabaran tersebut seperti: cara mengatasi hama serangga carica dieng yang diletakkan pada uraian sejarah dan tradisi, yang seharusnya penjabaran tersebut diletakkan pada uraian metode produksi dan pengolahan seperti yang terdapat pada Buku Persyaratan Indikasi Geografis kangkung lombok.

Temuan lainnya yaitu mengenai uraian Sejarah dan Tradisi, dimana tim peneliti menyimpulkan bahwa dari beberapa Buku Persyaratan yang penjabarannya sesuai dengan isi yang diharapkan oleh Pasal 6 ayat (3) Peraturan Pemerintah No. 51 Tahun 2007 tentang Indikasi Geografis yaitu uraian Sejarah dan Tradisi yang terdapat dalam Buku Persyaratan Indikasi Geografis Kopi Flores Bajawa. Pada Buku Persyaratan yang sama, dijabarkan

Copyright $\odot$ 2015, LITIGASI, p-ISSN: 0853-7100; e-ISSN: 2442-2274 
Available online at: http://ejournal.unpas.ac.id/index.php/litigasi

Litigasi, Vol. 16(1), 2015, 2582-2609

DOI: http://dx.doi.org/10.23969/litigasi.v16i1.93

pula mengenai metode kontrol dan keterunutan yang sebenarnya di dalam Pasal 6 ayat (3) Peraturan Pemerintah No. 51 Tahun 2007 tentang Indikasi Geografis tidak ditentukan. Didalam metode kontrol dan keterunutan dibahas mengenai kontrol mandiri, kontrol oleh kelompok petani, dan kontrol oleh MPIG.

Keseluruhan pemaparan di atas, baik mengenai perbedaan sistematika penyusunan dan substansi yang dijabarkan di dalam setiap uraian yang disyaratkan Peraturan Pemerintah tentang Indikasi Geografis, antara Buku Persyaratan dengan Peraturan Pemerintah tentang Indikasi Geografis tersebut, dan perbedaan dari masing-masing Buku Persyaratan satu sama lainnya, maka peneliti mencoba menemukan standar dalam menyusun sistematika dan substansi yang diharapkan dari sebuah buku persyaratan Indikasi Geografis Beras Pandanwangi Cianjur. Sistematika dan substansi yang terkandung di dalam Buku Persyaratan terdiri atas :

1. Nama Indikasi Geografis;

2. Nama Barang;

3. Karakteristik dan kualitas barang, yang di dalamnya berisi tentang:

a. sifat fisik benih, profil dan cita rasa produk;

b. sifat khas organoplatik, kandungan kimia penting;

c. deskripsi lingkungan geografis yang mengandung faktor alam diantaranya topografis, curah hujan, suhu dan kelembaban, dan tanah;

Copyright @ C 2015, LITIGASI, p-ISSN: 0853-7100; e-ISSN: 2442-2274 
Available online at: http://ejournal.unpas.ac.id/index.php/litigasi

Litigasi, Vol. 16(1), 2015, 2582-2609

DOI: http://dx.doi.org/10.23969/litigasi.v16i1.93

4. Faktor Alam dan faktor manusia, dimana faktor alam berisikan keterangan geografis, keterangan batas wilayah, iklim, sifat tanah dan ketersediaan air, sedangkan faktor manusia berisikan penjabaran tentang pengaruh perilaku dan kebiasaan yang dilakukan manusia terhadap kualitas dan karakteristik barang; metode proses mencakup panen dan perlakuan pasca panen yang berasal dari kearifan lokal; deskripsi tentang hubungan faktor alam dengan karakteristik yang dimiliki beras Pandanwangi Cianjur.

5. Peta Batasan Wilayah;

6. Metode Produksi dan Pengolahan barang yang berisikan sistem produksi, persiapan lahan, pengolahan lahan, persiapan bibit, metode pengolahan, pemasaran produk, penanaman, pengairan, pemupukan, pengendalian hama penyakit, panen, dan sistem penanganan pasca panen; metode kontrol dan kekhasan produk; pemberian sertifikat mutu kepada unit pengolahan produk; pengawasan distribusi produk; dan daftar bandar dan kelompok tani.

7. Sejarah dan Tradisi, yang berisikan tentang sejarah berdirinya kota, sejarah tentang barang yang terindikasi geografis, dan uraian tentang adat istiadat daerah asal barang yang terkait dengan budaya lokal menyangkut penanaman dan pengolahan serta pemasaran produk.

8. Metode Pengujian Mutu atau kualitas barang;

9. Metode kontrol dan keterunutan, yang berisikan kontrol mandori, kontrol oleh petani dan kontrol oleh MPIG;

Copyright @ 2015 , LITIGASI, p-ISSN: 0853-7100; e-ISSN: 2442-2274 
Available online at: http://ejournal.unpas.ac.id/index.php/litigasi

Litigasi, Vol. 16(1), 2015, 2582-2609

DOI: http://dx.doi.org/10.23969/litigasi.v16i1.93

10. Label.

Berdasarkan uraian di atas, standarisasi dalam penyusunan Buku Persyaratan secara keseluruhan sudah tercakup dalam Peraturan Pemerintah tentang Indikasi Geografis. Meskipun dalam praktik, penjabaran uraian Buku Persyaratan dalam Peraturan Pemerintah tentang Indikasi Geografis disikapi berbeda oleh MPIG. Aktualisasi pengetahuan dan pemahaman yang berbeda dari MPIG menjadikan beragamnya baik dari sisi tingkat ketebalan, muatan maupun substansi Buku Persyaratan yang disusun. Ke depan, standar dalam menyusun sistematika dan subtansi yang telah disusun peneliti akan mempermudah MPIG dalam menyusun Buku Persyaratan Indikasi Geografis.

B. Langkah-langkah penyusunan Buku Persyaratan Beras Pandanwangi Cianjur Sebagai Salah Satu Prasyarat Pendaftaran Indikasi Geografis

Mewujudkan Buku Persyaratan Indikasi Geogarfis selain memerlukan hal-hal yang bersifat administratif dan substantif juga memerlukan dana yang tidak sedikit. Oleh karena itu, Pemerintah Daerah dan masyarakat perlu menjalin komunikasi yang intern tentang pengalokasian dana pembuatan Buku Persyaratan ke dalam Rencana Anggaran Pendapatan Daerah (RAPBD). (Tatty A. Ramli dan Yeti Sumiyati, 2009) Selain itu, diperlukan langkah-langkah dalam menyusun uraian Buku Persyaratan agar paling tidak dapat memperpendek birokrasi yang selama ini kerap menjadi faktor penghambat penyusunan Buku Persyaratan.

Copyright $\odot$ 2015, LITIGASI, p-ISSN: 0853-7100; e-ISSN: 2442-2274 
Available online at: http://ejournal.unpas.ac.id/index.php/litigasi

Litigasi, Vol. 16(1), 2015, 2582-2609

DOI: http://dx.doi.org/10.23969/litigasi.v16i1.93

Berdasarkan deskripsi atau uraian yang harus diisi dalam Buku Persyaratan, maka langkah-langkah yang harus ditempuh dalam penyusunan Buku Persyaratan antara lain: 1) masing-masing dinas terkait, termasuk Bappeda Kabupaten Cianjur harus menyusun Renstra terkait langkah-langkah untuk mendapatkan perlindungan hukum Indikasi Geografis bagi Beras Pandanwangi Cianjur yang diawali dengan mendorong terbentuknya lembaga perwakilan untuk pendaftaran. Renstra ini disusun untuk diajukan pada proposal kegiatan yang dialokasikan dari APBD Kabupaten Cianjur. Konsolidasi perlu segera dilakukan untuk pertemuan antara pihak terkait, menentukan format lembaga, menentukan anggota peserta, menentukan susunan organisasi lembaga, mempelajari Peraturan Pemerintah, dan membuat agenda kerja; 2) Lembaga yang terintegrasi merupakan perwakilan dari komponen pihak terkait Beras Pandanwangi Cianjur, diantaranya unit kelompok tani, unit kerja masyarakat lokal, unit kerja Bandar atau produsen, unit kerja Dinas Pertanian, unit kerja Birokrasi Pemkab Cianjur, dan unit kerja Dinas Perdagangan.

Terkait dengan uraian dalam Buku Persyaratan, maka unit kelompok tani sangat kompeten membuat uraian tentang: perlakuan atau cara penanaman sampai panen dari mulai input sampai outcome, sifat fisik benih, profil dan cita rasa produk; metode produksi mencakup lahan dan persiapan lahan serta bahan tanam dan pembibitan; metode proses mencakup panen dan perlakuan pasca panen yang berasal dari kearifan lokal; dan metode kontrol

Copyright $\odot$ 2015, LITIGASI, p-ISSN: 0853-7100; e-ISSN: 2442-2274 
Available online at: http://ejournal.unpas.ac.id/index.php/litigasi

Litigasi, Vol. 16(1), 2015, 2582-2609

DOI: http://dx.doi.org/10.23969/litigasi.v16i1.93

keterunutan produksi dan proses. Unit kerja masyarakat lokal sangat kompeten membuat uraian tentang: sejarah beras Pandanwangi Cianjur; dan adat istiadat yang terkait dengan budaya lokal menyangkut penanaman dan pengolahan serta pemasaran beras Pandanwangi Cianjur.

Unit kerja Bandar atau produsen berkompeten membuat uraian tentang: informasi kualitas dan karakteristik produk yang disukai konsumen; metode pengolahan beras; metode pemasaran produk; dan metode proses pengolahan beras. Unit kerja Dinas Pertanian berkompeten membuat uraian tentang: deskripsi lingkungan geografis yang mengandung faktor alam diantaranya topografis, curah hujan, suhu dan kelembaban, dan tanah; deskripsi pengolahan padi pasca panen; deskripsi batas wilayah atau pemetaan yang terkait dengan karakteristik beras Pandanwangi Cianjur; dan deskripsi tentang hubungan faktor alam dengan karakteristik yang dimiliki beras Pandanwangi Cianjur.

Unit kerja birokrasi - Pemkab Cianjur sangat kompeten menyusun uraian tentang: metode kontrol dan keterunutan atas pemenuhan syarat-syarat dari Buku Persyaratan Indikasi Geografis; menentukan label logo Indikasi Geografis beras Pandanwangi Cianjur; dan pengawasan penjualan dan persaingan usaha yang sehat. Unit kerja Dinas Perdagangan kompeten menyusun uraian tentang: metode kontrol dan kekhasan beras; pemberian sertifikat mutu kepada unit pengolahan beras; pengawasan distribusi beras; dan daftar bandar dan kelompok tani.

Copyright @ C 2015, LITIGASI, p-ISSN: 0853-7100; e-ISSN: 2442-2274 
Available online at: http://ejournal.unpas.ac.id/index.php/litigasi

Litigasi, Vol. 16(1), 2015, 2582-2609

DOI: http://dx.doi.org/10.23969/litigasi.v16i1.93

Penyusunan uraian Buku Persyaratan sesuai kompetensinya masingmasing akan dirasa lebih efektif apabila dilakukan melalui diskusi secara terfokus atau Focus Group Discussion (FGD). FGD dilakukan sesuai unit kerja masing-masing yang hasilnya diolah secara sistematis sesuai standar dalam menyusun sistematika dan substansi Buku Persyaratan.

Tahapan kegiatan dari tiap unit kerja di atas akan memberikan gambaran bagi pemerintahan menyusun proposal kegiatan dan anggaran dana yang dibutuhkan menjelang dilaksanakannya pendaftaran Indikasi Geografis. Langkah-langkah harus segera direalisasikan mengingat waktu yang terpakai dari proses pendaftaran sampai dikeluarkannya sertifikat Indikasi Geografis minimal 3 tahun, sementara sistem pendaftaran untuk Indikasi Geografis adalah "first to file system " atau sistem konstitutif yang artinya hak Indikasi Geografis hanya diberikan kepada pemohon pendaftaran yang sudah dinyatakan lolos pada pemeriksaan administratif dan pemeriksaan substantif. Apabila terlambat melakukan pendaftaran, tidak menutup kemungkinan pihak lain akan melakukan pendaftaran beras Pandanwangi Cianjur dan masyarakat terkait beras Pandanwangi Cianjur kehilangan hak dan kewenangan atas nama Cianjur yang dapat merugikan dari sisi pencitraan daerah maupun komersil.

Seperti yang telah dijelaskan sebelumnya, pada dasarnya telah terjadi peningkatan pengetahuan dan pemahaman pihak yang berkepentingan terkait perlindungan hukum Indikasi Geografis Beras Pandanwangi Cianjur. Akan tetapi, peningkatan pengetahuan dan pemahaman masyarakat Kabupaten

Copyright $\odot$ 2015, LITIGASI, p-ISSN: 0853-7100; e-ISSN: 2442-2274 
Available online at: http://ejournal.unpas.ac.id/index.php/litigasi

Litigasi, Vol. 16(1), 2015, 2582-2609

DOI: http://dx.doi.org/10.23969/litigasi.v16i1.93

Cianjur terkait perlindungan hukum Indikasi Geografis belum menjamin terlaksananya pendaftaran. Hal ini seperti yang dijelaskan sebelumnya sangat tergantung dari tingkat kesadaran masyarakat yang berbanding lurus dengan faktor budaya masyarakat.

Faktor budaya inilah yang merupakan tantangan yang paling kuat dalam upaya menginternalisasikan konsep-konsep HKI ke dalam kerangka normatif masyarakat, untuk mendapatkan manfaat ekonomi dari pendaftaran. Terhadap suatu norma yang tidak berasal dari nilai-nilai yang mereka yakini, warga suatu masyarakat tidak akan berhenti meyakini "budaya lama", sampai mereka percaya sungguh-sungguh bahwa "hal yang baru" yang diintroduksikan dapat menjamin masa depan dan dapat mengganti jaminan yang diberikan oleh sitem lama yang diyakini.

Butuh waktu dan komitment yang kuat utamanya dari pemerintah untuk meyakini masyarakat bahwa prinsip-prinsip HKI utamanya perlindungan Indikasi Geografis merupakan rezim HKI yang paling relevan dilaksanakan dalam situasi dan kondisi masyarakat asli Indonesia. Sifatnya yang terkait dengan budaya, historis dan kekayaan lokal, serta kepemilikannya yang tidak berada pada individu melainkan komunal tidak akan merubah konsep-konsep kehidupan bermasyarakat yang selama ini hidup dan diyakini baik dalam masyarakat.

Faktor lain yang menyebabkan potensi Indikasi-Geografis belum dapat dimanfaatkan secara maksimal untuk menunjang pertumbuhan ekonomi 
Available online at: http://ejournal.unpas.ac.id/index.php/litigasi

Litigasi, Vol. 16(1), 2015, 2582-2609

DOI: http://dx.doi.org/10.23969/litigasi.v16i1.93

masyarakat, adalah terkait dengan aparat pemerintah daerahnya. Dengan berbagai potensi Indikasi-Geografis dalam meningkatkan pertumbuhan ekonomi masyarakat, sudah seyogyanya pemerintah memberikan perlindungan, dengan maksud menyediakan cara untuk menghindari penggunaan Indikasi-Geografis dengan cara apapun, dalam memberi tanda atau menampilkan barang yang dapat mengindikasikan atau mencitrakan bahwa barang yang diperdagangkan berasal dari suatu wilayah geografis yang bukan dari tempat asal yang sebenarnya. Bentuk perlindungan dari pemerintah bagi kepentingan masyarakat dapat dilakukan dengan mendukung usaha masyarakat kearah pendaftaran berupa misalnya melakukan pemetaan terhadap produk Indikasi-Geografis di daerahnya, menyediakan fasilitas untuk melengkapi persyaratan - persyaratan teknis administratif untuk pendaftaran produk Indikasi-geografis, dan sebagai mediator terbentuknya Pemohon pendaftar (Tatty A, Ramli \& Yeti Sumiyati, 2008).

Diyakini bahwa dari seluruh rezim HKI yaitu Paten, Merek, Hak Cipta, Rahasia Dagang, Desain Industri dan Tata Letak Sirkuit Terpadu, maka rezim Merek yang di dalamnya tercakup perlindungan Indikasi Geografis merupakan rezim yang paling besar peluangnya untuk diimplementasikan oleh Indonesia sebagai Negara berkembang yang berbasis agraria. Pernyataan di atas didukung oleh fakta-fakta bahwa:

Copyright $\odot$ 2015, LITIGASI, p-ISSN: 0853-7100; e-ISSN: 2442-2274 
Available online at: http://ejournal.unpas.ac.id/index.php/litigasi

Litigasi, Vol. 16(1), 2015, 2582-2609

DOI: http://dx.doi.org/10.23969/litigasi.v16i1.93

1. Indonesia adalah Negara tropis yang potensi keanekaragaman hayatinya sangat terbuka memiliki kualitas dan karakteristik yang berbeda dengan wilayah lain.

2. Perlindungan Indikasi Geografis sifat kepemilikannya komunal, tidak bersifat individu seperti pada rezim HKI lainnya sehingga berkesesuaian dengan paham kepemilikan di banyak komunitas masyarakat Indonesia.

3. Bahwa yang menjadi objek dari perlindungan ini adalah hasil alam atau kerajinan yang berasal dari kearifan lokal masyarakat yang banyak ditemui di Indonesia.

4. Potensi Indikasi Geografis yang demikian besar dapat mengimbangi keunggulan Indonesia dalam memanfaatkan HKI sebagai asset komersial. Titik beratnya ada pada kesiapan potensi Sumber Daya Manusia, ilmu pengetahuan dan modal yang mana merupakan kelemahan bagi bangsa Indonesia.

Oleh karenanya, perhatian pemerintah pusat menggalakkan pemanfaatan produk Indikasi Geografis di seluruh nusantara melalui hasil-hasil alam yang berkualitas dan berkarakter khusus harus terus didukung. Kalangan akademisi memiliki peran strategis dalam mengedukasi masyarakat dan pemerintah daerah tempat asal produk Indikasi geografis.

Copyright @ $\odot$ 2015, LITIGASI, p-ISSN: 0853-7100; e-ISSN: 2442-2274 
Available online at: http://ejournal.unpas.ac.id/index.php/litigasi

Litigasi, Vol. 16(1), 2015, 2582-2609

DOI: http://dx.doi.org/10.23969/litigasi.v16i1.93

\section{SIMPULAN DAN SARAN}

A. Simpulan

1. Peraturan Pemerintah No. 51 Tahun 2007 tentang Indikasi Geografis mengatur mengenai muatan yang harus ada dalam sebuah Buku Persyaratan. Uraian tersebut berfungsi sebagai pedoman bagi MPIG dalam menyusun Buku Persyaratan. Standarisasi uraian dalam penyusunan Buku Persyaratan pada Peraturan Pemerintah akan menyulitkan MPIG karena produk Indikasi Geografis memiliki beragam varietas (produk pertanian dan hasil kerajinan).

2. Masing-masing dinas terkait, termasuk Bappeda Kabupaten Cianjur, harus menyusun Renstra terkait langkah-langkah untuk mendapatkan perlindungan ocal Indikasi Geografis bagi Beras Pandanwangi Cianjur yang diawali dengan mendorong terbentuknya lembaga perwakilan untuk pendaftaran atau MPIG. Langkah - langkah penyusunan Buku Persyaratan Lembaga diawali dengan pembagian tugas kepada unit yang dibentuk sesuai kompetensinya, diantaranya unit kelompok tani, unit kerja masyarakat ocal, unit kerja Bandar atau produsen, unit kerja Dinas Pertanian, unit kerja Birokrasi Pemkab Cianjur, dan unit kerja Dinas Perdagangan. Penyusunan uraian Buku Persyaratan sesuai kompetensinya masing-masing akan dirasa lebih efektif apabila dilakukan melalui diskusi secara terfokus atau Focus Group Discussion (FGD).

Copyright @ C 2015, LITIGASI, p-ISSN: 0853-7100; e-ISSN: 2442-2274 
Available online at: http://ejournal.unpas.ac.id/index.php/litigasi

Litigasi, Vol. 16(1), 2015, 2582-2609

DOI: http://dx.doi.org/10.23969/litigasi.v16i1.93

B. Saran

1. Peraturan Pemerintah tentang Indikasi Geografis perlu menambahkan ketentuan tentang sistematika dan substansi mengenai uraian - uraian yang bisa menunjukkan karakter dan kekhasan masing-masing produksi indikasi geografis yang mencakup produk pertanian dan hasil kerajinan.

2. Peraturan Pemerintah harus memuat ketentuan yang mengatur tentang peran dan fungsi pemerintah dalam mendorong terlaksananya langkahlangkah pendaftaran produk indikasi geografis dari seluruh pemangku kepentingan.

Copyright @ C 2015, LITIGASI, p-ISSN: 0853-7100; e-ISSN: 2442-2274 


\section{DAFTAR PUSTAKA}

\section{BUKU}

Miranda Risang Ayu. 2006. Memperbincangkan Hak Kekayaan Intelektual Indikasi Geografis. Bandung: Alumni.

Muhamad Jumhana. 2006. Perkembangan Doktrin dan Teori Perlindungan Hak Kekayaan Intelektual. Bandung: Citra Aditya Bakti.

M. Yahya Harahap. 1996. Tinjauan Merek Secara Umum dan Hukum Merek di Indonesia berdasarkan Undang-Undang Nomor 19 tahun 1992. Cetakan Pertama. Bandung: Citra Aditya Bakti.

Ronny Hanitijo Soemitro. 1994. Metodologi Penelitian Hukum dan Jurimetri. Jakarta: Ghalia Indonesia.

Soerjono Soekanto. 1986. Pengantar Penelitian Hukum. Jakarta: UI Press.

\section{JURNAL}

Tatty A. Ramli \& Yeti Sumiyati. 2009. Model Integrasi Lembaga Perwakilan untuk Pendaftaran sebagai Alternatif Pendaftaran untuk Memperoleh Perlindungan Hukum Indikasi Geografis Ubi Cilembu. Artikel Hasil Penelitian dalam Jurnal Hukum dan Pembangunan - UI. Tahun ke-39 Nomor 1 Januari.

Tatty A. Ramli \& Yeti Sumiyati. 2008. Implikasi Pendaftaran Indikasi Geografis Terhadap Potensi Peningkatan Pertumbuhan Ekonomi Masyarakat. Artikel dalam Jurnal Hukum Bisnis. Vol. 27 No. 24.

Yeti Sumiyati. 2010. Perbuatan Curang dalam Penggunaan Produk Indikasi Geografis. Artikel dalam Jurnal Sosiohumaniora. Vol. 12 No. 2 Juli.

\section{HASIL PENELITIAN}

Tatty A. Ramli dan Yeti Sumiyati. 2009. Diseminasi Model Integrasi Lembaga Perwakilan untuk Pendaftaran sebagai Alternatif Pendaftaran untuk Memperoleh Perlindungan Hukum Indikasi Geografis Ubi Cilembu Kabupaten Sumedang. Laporan Hasil Penelitian Hibah. 
Bersaing Lanjutan yang dibiayai oleh Direktorat Jenderal Pendidikan Tinggi. Departemen Pendidikan Nasional. Sesuai dengan Surat Perjanjian Pelaksanaan Hibah Penelitian Nomor: 040/SP2H/PP/DP2M/IV/2009. Maret 2009.

\section{MEDIA MASSA}

Handri Handrian. Elegi Pandan Wangi. Pikiran Rakyat. Rabu 10 Juni 2009.

\section{WEBSITE}

Peta Wilayah Indikasi Geografis Terdaftar. http://www.dgip.go.id/. diakses 05 Oktober 2013.

Anonim. Bertambah, Produk Indikasi Geografis yang Dilindungi: Ketimbang ribut dengan negara tetangga, lebih baik ajukan permohonan resmi demi perlindungan hukum.

http://www.hukumonline.com/berita/baca/lt4f13f7ae4f8ec/bertambahproduk-indikasi-geografis-yang-dilindungi. diakses 05 Mei 2013.

Anonim. Beras Pandan Wangi Oplosan beredar di Cianjur. http://www.indosiar.com/fokus/59964/beras-pandan-wangi-oplosanberedar-di-cianjur. 24 Maret 2007.

\section{PERATURAN PERUNDANG-UNDANGAN}

Undang-Undang Nomor 15 Tahun 2001 Tentang Merek.

Peraturan Pemerintah Nomor 51 Tahun 2007 Tentang Indikasi Geografis. 